\title{
A Double Thucydides Trap
}

Donald Trump's Presidency and New Bipolarity

\section{Dmitry V. Yefremenko}

\author{
Dmitry V. Yefremenko, Dr. of Political Science \\ Institute of Scientific Information on Social Sciences, \\ Russian Academy of Sciences, Moscow, Russia. \\ Deputy Director
}

SPIN-RSCI: 4587-9262

ORCID: 0000-0001-6988-472X

Researcher ID: Q-1907-2016

Scopus AuthorID: 55372669100

Tel: +7 (499) 124-3201

E-mail: efdv2015@mail.ru

Address: 51/21 Nakhimovsky Prospect, Moscow 117997, Russia.

This article partly summarizes the author's contribution to a collective monograph The Trump Phenomenon prepared by the Institute of Scientific Information on Social Sciences of the Russian Academy of Sciences and scheduled for release in September 2020.

DOI: $10.31278 / 1810-6374-2020-18-3-76-97$

\begin{abstract}
Donald Trump's presidency steered U.S.-China relations into a phase of open rivalry for global domination. The U.S. has failed to sidestep the risk of confrontation with China that Graham Allison warned of with his "Thucydides trap" metaphor. The two countries' strongest trading and economic interdependence has proven unable to prevent a political standoff between Washington and Beijing. Their competition in science and engineering may result in the emergence of two technoeconomic platforms other countries will have to choose between. At the same time, the new U.S.-Chinese bipolarity is far more complex and internally controversial, which is a reason enough to postulate the existence of a "double Thucydides trap." Importantly, global development is being greatly influenced by the interaction within the U.S.-China-Russia triangle.
\end{abstract}


Keywords: the Thucydides trap, the United States, Donald Trump, China, Russia, bipolarity, Chimerica, geopolitical rivalry, world order, COVID-19 pandemic.

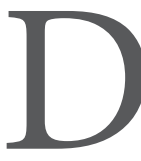

onald Trump's hectic (if not chaotic) presidency is steaming at full throttle towards an imminent point where it will either come to a halt or gain a second wind. At the beginning of 2020 many believed that the U.S. administration would retain a major competitive edge, with the Dow Jones Industrial Average reaching new highs and the main political opponents of the man in the White House falling into a deep stupor. The novel coronavirus pandemic and the ensuing profound economic crisis have practically "zeroed out" (to use the popular term in Russia's modern political parlance) most of Trump's real and propagandistic achievements. The racial tensions-fueled unrest that followed shook the foundations of the American giant. But in what concerns U.S. foreign policy the coronavirus crisis has not brought about any radical change yet. On the contrary, Washington tends to use the situation to the maximum extent to step up pressure on its main geopolitical rival.

Donald Trump's foreign policy philosophy stemmed from a rather realistic evaluation of long-term threats to U.S. domination. According to this evaluation it is China, and not Russia, that will be the United States' worst rival in the 21 st century. Consequently, the Trump administration was to focus on an all-out resistance to China's further rise and on efforts to stabilize relations with Russia.

As the 2020 presidential election draws near, one can say with certainty that the Trump administration has achieved relative success only in addressing the first task. As a result, the new U.S.-Chinese bipolarity is becoming the dominant factor in world political and economic development. Is this a reason enough to postulate that the United States under Trump has fallen precisely into the Thucydides trap that Graham Allison warned of (Allison, 2017) in his analysis of the Peloponnesian War, triggered largely by the fears of the domineering 
power-Sparta-of the growing potential of its main rival Athens? It looks like global geopolitical competition has caught the main world actors in a trap that has turned out to be far more intricate than the one Allison wrote about. Firstly, the fear that the hegemon may experience in the face of a quickly growing contender for hegemony has another side to it. Namely, starting from a certain point the contender may conclude that the hegemon is already in the Thucydides trap and will be doing its utmost to prevent-at any acceptable cost - the contender from gaining more strength. Secondly, one should not forget that there is a country that succeeded the former chief geopolitical and ideological opponent of the United States. After a decade of depression Russia has managed to regain part of its original might while retaining the same degree of strategic autonomy as China and the United States. Thirdly, there is a group of countries lacking full-fledged strategic autonomy that have been allies of the current hegemon since the era of its confrontation with the Soviet Union but that are beginning to feel uneasy whenever invited to play the same role in the U.S.-Chinese confrontation.

\section{TRUMP AND CHINA}

Donald Trump's actions were meant to bring U.S. policies towards China in line with the preconceptions of the American political elite, which had mentally fallen into the Thucydides trap even before the beginning of Trump's election campaign. President Xi Jinping hinted at this quite plainly in the fall of 2015: "There is no such thing as the socalled Thucydides trap in the world. But should major countries time and again make the mistakes of strategic miscalculation, they might create such traps for themselves" (President Xi’s Speech, 2015).

By the middle of the second decade of the 21 st century the United States and China had for many years been in a state of stable and paradoxical interdependence. Neil Ferguson coined an ironic term for it-Chimerica, which instantly stuck (Ferguson and Schularick, 2007). The U.S.-Chinese trading and economic symbiosis emerged as a result of America's super-consumption and China's export expansion. The revenue from the latter fueled Beijing's massive acquisition of U.S. 
government bonds, thus encouraging further growth of consumer demand in the U.S. The effect of Chimerica was truly global: return on equity grew everywhere and interest rates and labor costs went down (Ferguson and $\mathrm{Xu}, 2018$ ). In the meantime, in the United States itself many industries turned uncompetitive, while China, having gained the status of the world's factory in the 21 st century, was already making investments not only in U.S. bonds but, above all, in the newest technologies, infrastructures, and human resources. The 2008 crisis, largely triggered by Chimerica, among other things, did not disrupt the interdependence of Washington and Beijing. On the contrary, it established a substantially different balance of political and economic losses, this time considerably in China's favor.

The fact that Chimerica benefited China first and foremost drew a mixed response inside the United States. On the one hand, the alarmists, such as Peter Navarro, made their voices increasingly heard (Trump would eventually appoint Navarro as National Trade Council Director).

Navarro's works contain a long list of anti-Chinese arguments that Trump would later use in his election campaign (Navarro and Autry, 2011). They include manipulations with the Chinese currency's exchange rate, export subsidies that reduce to nothing the very possibility of U.S. companies' competition with Chinese ones, unprecedented violations of intellectual property rights, coercion of U.S. companies into the transfer of sensitive technologies and direct industrial espionage, export of low-quality and hazardous consumer goods to the U.S., restrictions on the freedom of access to cyberspace, violations of human rights and rights of minorities, exponential growth of military spending, pressure on Taiwan, and China's increased presence in the South China Sea posing a threat to its neighbors. The main conclusion was that the Red Dragon must be stopped before it was too late.

On the other hand, the proponents of the mild approach came up with a "too big to fail" argument: Chimerica is so large that the costs of decoupling would be exorbitant for both the United States and China. For this reason, both countries would eventually have to 
devise a lasting modus vivendi in political relations. The Barack Obama administration turned an attentive ear to the alarmists' warnings and preferred to stay closer to those who called for "taming the dragon." The Pivot to Asia doctrine, which was the 44th U.S. president's reaction to China's economic, military and political boom, meant to combine the containment of China with its conversion into a strategic partner that would pose no threat to U.S. regional security structures (National Security Strategy, 2010). Two U.S.-centric trading and economic super-blocs-Trans-Pacific Partnership and Transatlantic Trade and Investment Partnership-were expected to guarantee the United States' decisive advantage.

Trump acted on his election pledges to discard Obama's foreign policy legacy on the Chinese track. At the doctrinal level, the Trump administration expressed quite a Hobbesian view of the international order as a field of open competition among states for influence: "These competitions require the United States to rethink the policies of the past two decades-policies based on the assumption that engagement with rivals and their inclusion in international institutions and global commerce would turn them into benign actors and trustworthy partners. For the most part, this premise turned out to be false" (National Security Strategy, 2017). The U.S. National Security Strategy approved in 2017 describes China and Russia as "revisionist powers" set to achieve a revision of the U.S.-led world order.

On the very first day after his inauguration Trump declared the United States' pullout from the TPP, which, he said, was a "bad deal" harmful to the U.S. economy, causing the loss of millions of jobs and restricting national sovereignty. In accordance with the "America First" slogan Trump began to dismantle the previous architecture of multilateral trade agreements which had been built by consistent efforts of several previous administrations. In fact, Trump preferred to drop the advantages of domination within multilateral systems of international cooperation. Instead of using them for restricting China's economic and political potential, Trump opted for "one-onone" confrontation and a far wider range of arguments and means of pressure. The Trump administration staked on bilateral agreements, for 
it was certain that in this way the U.S. would build up its advantages. However, it certainly overlooked the fact that multilateral economic agreements allow for exercising the greatest control of transnational value-added chains. Thus the U.S. clearly opened up far broader opportunities for such China-centric multilateral initiatives as the Regional Comprehensive Economic Partnership and, in particular, One Belt One Road. The impression that there had happened a change of leadership grew still stronger after the 2017 Davos Forum (the yet-tobe formed Trump administration was absent from the event), where $\mathrm{Xi}$ Jinping, the General Secretary of the CPC Central Committee, unexpectedly positioned himself as a proponent and almost main advocate of liberal globalization.

After year-long preparations the Trump administration unleashed a trade war on China. It began in January 2018 with rather moderate tariff measures but soon acquired extraordinary dimensions embracing Chinese goods and services worth $\$ 250$ billion. The conflicting parties took rather firm negotiation positions, but the American side kept increasing pressure and more than once upped the antes on other tracks. The standoff was not confined to the escalation of tariff restrictions only; the American side employed a combined tactic, using political pressure, media resources, and even judicial mechanisms. The arrest of Huawei's CFO Meng Wanzhou in Canada in 2018 at the U.S. request was a marquee event. Apparently, Washington's determination to deny immunity to representatives of the Chinese economic elite was a clear indication that the point of no return in the U.S.-Chinese confrontation had been passed. Washington's further sanctions and pressure on Huawei, ZTE and other Chinese high-tech companies under the pretext that they had been selling equipment containing U.S.-made parts and components to Iran showed that the main aim in this conflict was not a reduction of the U.S. deficit in trade with China or countermeasures against manipulations with the exchange rate of the Chinese currency, but prevention of China's global technological superiority.

U.S.-Chinese trade negotiations may well be likened to a rollercoaster ride. However, by the end of 2019 considerable progress had been achieved. With the impeachment procedures in progress and 
the presidential election campaign getting underway it was essential for the Trump team to demonstrate a breakthrough in the talks with China. The Chinese leadership, confronted with major political and economic problems, felt it was crucial to take a break and wait for the outcome of the U.S. presidential election and regroup forces ahead of another round of global rivalry.

On January 15, 2020, Trump and Vice-Premier of China's State Council Liu He met in Washington to ink documents regarding the first phase of the trade deal. This agreement does not dismantle the Chimerica model but eliminates the strongest distortions that played into China's hands. Specifically, China pledged to refrain from devaluations of its national currency in an attempt to gain trade advantages; in response, the U.S. Department of the Treasury removed China from the list of currency manipulators. Beijing's promise to purchase an extra $\$ 200$ billion worth of U.S. goods is not a result of economically well-founded choice by Chinese companies, but of direct instructions from China's political leadership. To a certain extent this will straighten out the trade imbalance, but by no means bring about changes in the entire structure of U.S.-Chinese trade relations. Apparently, European manufacturers will be the first ones to lose a certain share of the Chinese market. The Trump administration does not care at all this agreement represents a major departure from the liberal principles and WTO rules.

With Trump in office, the U.S. has considerably stepped up pressure on China over the most sensitive political and humanitarian issues. For instance, the Uyghur Human Rights Policy Act, approved by both chambers of the U.S. Congress, provides political and legal grounds for U.S. intervention in Xinjiang and, just like the Magnitsky Act concerning Russia, opens up an opportunity to impose sanctions on Chinese officials and companies responsible for the violations of Uyghurs' rights. The Hong Kong Human Rights and Democracy Act not only creates another set of sanction tools, but allows for introducing amendments to the special status of trade relations between the U.S. and Hong Kong. The strong moral and information support which the United States and some other Western countries furnished for 
protesters in Hong Kong in 2019 entailed no less tangible political effects. Possibly, Washington merely sought to persuade China to soften its position on the terms of the trade deal. However, such vigorous attempts by the U.S. to play the Uyghur and Hong Kong cards (with the Tibetan card being kept up the sleeve) were sufficient reasons for Beijing to make rather alarming conclusions. The Chinese leadership had to draw up the National Security Law, which considerably enhanced Beijing's control of security issues and in fact heralded partial revision of Hong Kong's autonomy. Trump used this forced step as a good pretext to declare that the preferential terms of trade with Hong Kong would be revised and a number of other agreements on economic, technological and humanitarian trade with the former British colony rescinded.

The moment it used Hong Kong and Xinjiang as political arguments Washington stepped over another red line in relations with China. The worst internal threat to China's security exists precisely in Xinjiang. Whereas the Uyghur problem is a long-standing one and invariably remains within the Chinese leadership's focus of attention, the events in Hong Kong may instantly turn the special autonomous region Xianggang from a showcase of the "one country-two systems" model and its historical success into Beijing's Achilles' heel. Achieving a lasting political solution in Hong Kong that would suit everybody is hardly possible, but radical actions that might fundamentally change the political situation in this "global city" are even more unlikely. In a word, conditions are being created for turning Hong Kong into a persistent source of political turbulence that Washington might use for its own purposes. Moreover, CPC analysts who have carefully studied the history of the Soviet Communist Party's collapse and the breakup of the Soviet Union are well aware that if synchronized, strong external pressure, the risk of a socio-economic crisis inside the country, emergencies, an upsurge of peripheral separatism and political protests in the center may cause a catastrophic scenario. In fact, China was on the verge of such a crisis during student demonstrations in Tiananmen Square in the spring of 1989. The authorities in Beijing are perfectly aware that in such a situation, albeit a very hypothetical one, any U.S. 
administration will use every opportunity to try to inflict a crushing defeat on the main geopolitical rival by nonmilitary means. The same applies to Russia. In Russia, the U.S. leadership will demonstrate a little bit more restraint only if there is a risk that the country's nuclear potential may go out of control, and also if Beijing might become the main beneficiary of Russia's disintegration.

\section{GLOBAL STRATEGIC TRIANGLE}

The "reverse Nixon" stratagem has become something of a nightmare for a cohort of U.S. pundits and columnists studying comprehensive interaction among leading actors in the current system of international relations (Burrows and Manning, 2015). Over the past twenty years the possibility the U.S. may experience the backlash effect of the memorable diplomatic maneuver Richard Nixon and Henry Kissinger performed in the early 1970s has been discussed each time Russia and China made significant steps towards each other. The tradition of looking at the changing global balance of power through the lens of trilateral relations among Washington, Moscow, and Beijing goes back to the Soviet era (Dittmer, 1981; Goldstein and Freeman, 1990).

Currently, these three powers are in the lead by all or some indicators, such as military, economic, scientific and engineering potentials and natural resources. Two of them claim to take the leading positions within the framework of the existing or future world political and economic order; and the third power, while laying no such claims, enjoys a relatively high freedom of political maneuver and real opportunities to exert critical influence on the transformation of the world order. Even though formalized trilateral cooperation between the sides of this triangle does not exist, there is a certain power field that has a strong impact on the world order in general. Each side, whenever it takes action that may influence the strategic behavior of another side, considers a likely response from the third side (Jervis, 1997; Degterev and Istomin, 2015). The configuration of this triangle is rather stable, but inside it the balance of power constantly changes, with each side enjoying a sufficient degree of autonomy of action (in contrast to such major powers as Britain, France, Germany or Japan, which have rigid 
allied obligations to the United States) that enables them to create a situation of strategic uncertainty for the others. In defining a balance of power inside the U.S.-Russia-China triangle that would be most favorable to the United States, Henry Kissinger proposed the following formula: "Our relations to possible opponents should be such that our options to both of them were always greater than their options towards each other."

The U.S. administrations from Nixon to Obama managed to maintain a balance of power inside the strategic triangle that was favorable to Washington but at the same time avoided the institutionalization of trilateral interaction. Before the Trump team took over the White House, the U.S. expert community showed no unanimity regarding trilateral cooperation prospects. Shortly before his death, Zbigniew Brzezinski offered a moderately optimistic forecast of opportunities for cooperation by the three powers. In his opinion, it is crucial to prevent a global collision and to settle regional conflicts which the three powers are capable of influencing. Brzezinski mentioned in passing the main reason that should encourage the United States to seek trilateral cooperation, namely, the risk of an alliance between Russia and China. He insistently underscored the advantages of the trilateral format for Russia, because bilateral cooperation will sooner or later make Moscow encounter Beijing's attempts to weaken Russia's foothold in the post-Soviet space and, possibly, territorial claims that may surface even though all border issues were settled in the 2001 Treaty of Good-Neighborliness and Friendly Cooperation.

A considerably different approach to interaction with America's main adversaries was formulated ahead of Trump's presidency by representatives of modern political realism John Mearsheimer and Stephen Walt (2016). As they developed the concept of offshore balancing, the authors described an alternative policy of preserving America's total domination at any cost. Instead of excessive efforts, which with a high degree of probability will turn out futile, Mearsheimer and Walt suggested focusing on three key regions where the United States really has vital interests-Europe, Northeast Asia, and the Persian Gulf. From the military strategic standpoint, offshore 
balancing is meant to neutralize the enemy's advantage in a key region (for instance, China's advantage in the Taiwan Strait or Russia's advantage in the post-Soviet space) by creating threats in another region vital to it, where it does not have an obvious advantage, and also to maximize the costs of the use of force. It should be noted, however, that resistance to China in accordance with the offshore balancing concept in East Asia and simultaneous containment of Russia in the post-Soviet space cannot remain isolated from each other all along. As a result, China and Russia will have more incentives to seek further rapprochement and resist the power that blocks their efforts to gain a firmer foothold in the regions they find most important.

Another part of the U.S. expert community insisted that Washington should adhere to substantially different approaches in interacting with Beijing and Moscow. RAND Corporation experts said China and Russia should not be placed in one group of "revisionist powers," contrary to what was done in the Trump administration's "National Security Strategy." They argue that China demonstrates a more acceptable and responsible type of behavior on the world scene. It presses for geoeconomic advantages first and foremost, and gradually shifts the global balance of power in its favor. Respectively, in the long term, China constitutes a far more serious challenge to the United States. Russia, on the contrary, has no chance of becoming a dominant power no matter how the world may change, but in the short term its behavior creates the most dangerous challenges: Russia "has attacked neighboring states, annexed conquered territory, and supported insurgent forces"; it "interferes in foreign elections, subverts foreign democracies, and works to undermine European and Atlantic institutions" (Dobbins, Schatz and Wyne, 2018, p.2). For this reason, only China deserves the status of the United States' full-fledged rival, while Russia should be treated as a rogue state and destabilizing measures are quite permissible to make it change its behavior. Washington's different polices towards Beijing and Moscow are expected to create an illusion that for the United States there exist only bilateral formats of interaction with the main geopolitical opponents, while changes in the balance of power inside the strategic triangle are not taken into account at all. 
The United States' actual policy within the strategic triangle during the Trump presidency should rather be described as eclectic, combining certain elements borrowed from each of the approaches described above, but at the same time not identical to any of these strategies. It is beyond doubt that Washington's pressure on Moscow and Beijing has served as a powerful factor for tighter Russia-China partnership: the two countries are demonstrating not only impressive growth in cooperation, but also a markedly new level of mutual trust. In 20172018 the share of the Chinese national currency (renminbi) in Russia's gold and foreign exchange reserves went up 150 times. Another telling sign of the level of trust between Moscow and Beijing can be seen in President Vladimir Putin's statement that Russia provides major assistance to China in creating its own missile attack warning system (Valdai, 2019). This statement is also evidence that military-technical cooperation between the two countries is increasingly determined by confrontation with the U.S. The two countries' geographic location is very favorable for deeper cooperation in defense and dual-use technologies and lets them assist each other in enhancing means and forces crucial to deterring the U.S. At the same time, in case of a hypothetical worsening of bilateral relations either country will need a different set of forces and military means (Kashin, 2019). Russia creates a gigantic strategic depth for China and-together with the Central Asian countries-a tremendous gap in the string of countries that neighbor China and to a greater or smaller extent are oriented towards military-political partnership with the United States. China plays a similar role for Russia, and it will play this role at least as long as Moscow sees the United States and the collective West as the main source of military and political threats.

\section{GEOPOLITICAL REALIGNMENT}

\section{ALONG TECHNOECONOMIC PLATFORMS}

The transition to a long-term standoff between Washington and Beijing is the fundamental result of Trump's policies on the Chinese track. Global leadership is the prize at stake. The compromise solutions to trade issues that were achieved in 2020 should not let anyone feel 
complacent. China's response to Trump's challenge will be systemic and fundamental. It will have political, diplomatic, informational, military, financial, and economic dimensions, but its key element is Beijing's decision to create its own technoeconomic platform, independent from the West in terms of standards, infrastructure support, and provider chains.

The ten-year plan "Made in China 2025" and the "Internet Plus" strategy adopted in 2015 are targeted at comprehensively upgrading the technological basis of the Chinese economy and achieving new frontiers in the key fields of science and engineering. While being market-oriented, these programs at the same time imply the Chinese state's massive participation in breeding national technological champions. The government's contribution to import substitution and overall technological breakthrough will require a wide range of toolsfrom direct subsidizing and creation of preferential regimes to the actual compulsion of foreign companies that are eager to do business in China to share their technologies.

Originally the "Made in China 2025" plan focused largely on eliminating the lag by bringing the share of Chinese manufacturers on the domestic market to $70 \%$ by 2025 , halving operating costs and reducing the duration of production cycles and the amount of faulty and substandard products. However, key figures in the Trump administration are voicing far more alarmist opinions. For instance, U.S. Attorney-General William Barr said at the beginning of 2020 that the Communist Party of China "has mobilized all elements of Chinese society-all government, all corporations, all academia, and all of its industrious people-to execute seamlessly an ambitious plan to dominate the core technologies of the future" (Barr, 2020).

According to Ian Bremmer, the combination of the "Made in China 2025" plan and the "Internet Plus" strategy "is the single most consequential geopolitical decision taken in the last three decades" and "the greatest threat to globalization" (Bremmer, 2019). Creation of a Chinese technoeconomic platform will cause a fundamental split, which in fact is already underway in the field of information and communication. 
There have been many indications that the destruction of the Chimerica symbiosis will proceed at the technological level and eventually spread to other spheres of interaction. China and the United States will create two competing and ever less compatible global ecosystems for the development of the Internet, big data processing technologies, 5G mobile communication, additive technologies, robotics, etc. This will be accompanied by greater divergency of regulatory regimes. The choice of a technoeconomic platform will be a geopolitical choice as well. Presumably, such a choice will have to be made by all actors involved in the system of international relations. Geopolitics and internal political reasons will in many cases outweigh considerations of economic and technological expediency. It is highly probable that in Russia's case it will happen precisely this way. Unlike the Soviet Union, Russia possesses far less opportunities for creating its own technoeconomic platform. It looks like the transition to the Chinese technological platform will have no alternative there where Russia’s opportunities for achieving technological independence are most limited.

Other Eurasian Economic Union member states will follow in Russia's footsteps to make this transition, too. Such countries as Iran, Pakistan, North Korea, a number of Arab, sub-Saharan states, and Cuba, Venezuela, and Nicaragua in Latin America have practically no alternative to making such a choice, provided their current regimes stay in power for a long time. Also, a large group of countries will find themselves in the orbit of U.S.-China competition; already now many of them are active participants in the One Belt One Road initiative.

\section{TRIAL BY THE CORONACRISIS}

"The ideal storm" of 2020-the COVID-19 pandemic, the global lockdown and the ensuing acute economic crisis-has turned out to be a major test for the strengths and vulnerabilities of countries around the world. China, which was the first to take the hard blow of the COVID-19 pandemic and make a number of serious mistakes at its early stage, hurried to take unprecedentedly harsh quarantine measures to isolate or restrict the freedom of movement for more than 
700 million people. As a result, in March 2020 the Chinese government put the epidemic under control and even began to render assistance to a number of other countries, providing medical equipment and personnel. Although it sustained enormous economic losses, China was the first major country to turn the tide in the struggle against the coronavirus, thus demonstrating to the whole world the mobilization potential, and the strength and effectiveness of its sociopolitical system.

Against this background actions taken by Trump and his administration first looked like attempts to belittle the epidemic threat, and then like a series of impulsive measures in an attempt to compensate for the missed opportunities in the struggle against the proliferation of the coronavirus across the country. As the epidemiological situation turned from bad to worse and the accompanying economic losses soared, the American authorities ever more insistently emphasized the Chinese origin of the virus, for which purpose they used such terms and the 'Wuhan virus' or 'Chinese virus.' The narrative of China's responsibility for the pandemic and the economic crisis became a major feature of Trump's election rhetoric.

At the beginning of May 2020, U.S. Secretary of State Michael Pompeo declared he was certain that the Wuhan Institute of Virology was the original source of the coronavirus. The Trump administration must have managed to persuade a large part of the U.S. electorate that the responsibility for the pandemic and the economic crisis must be placed squarely on China. A negative shift in the attitude towards China is observed in key EU countries, Britain, and Australia. Further escalation of the anti-Chinese campaign, in particular, the imposition of sanctions for concealing information and lawsuits against China for the compensation of losses from the pandemic may cause catastrophic damage to U.S.-China bilateral relations. Trump went as far as mentioning the possibility of severing relations with China altogether.

It is beyond doubt that the coronavirus crisis will boost the rearrangement of the world political and economic order. Already now the scale of the crisis requires collective decisions and actions. In deciding what actions to take and in what sequence China seems in a far more favorable position now than the United States. 
Washington still has the greatest opportunities for influencing the crisis dynamics, but the Trump administration's ability to use this potential within the framework of collective and concerted international efforts is rather limited.

One way of another, as the coronavirus crisis rolls on, the international community is sliding ever faster towards new confrontational bipolarity. Neither a common threat to the whole of humanity nor the still remaining trading and economic symbiosis of the two irreconcilable adversaries has been able to stop this process. However, the Thucydides trap is in place not only for the United States and China. Its design is far more intricate, and, regrettably, Russia is not very far away from it either.

\section{NEW BIPOLARITY AND RUSSIA}

The balance of interaction among the three key powers of the modern world can be presented as a dynamic correlation of the factors of strength and the factors of vulnerability of each of them. Obviously, it is impossible to exclude from this correlation either the objective parameters that characterize the condition of the economy or the armed forces, or the combination of objective and subjective factors that determine the degree of the political system's consolidation, or the media image of the state leader that has a tangible effect on the perception of his steps on the international scene and inside the country. In this sense the symbolic meaning of Donald Trump's personality and his manner of behavior in relations with U.S. allies and adversaries are no less significant than the package of specific decisions made during his presidency with regard to China and Russia.

Trump was not the cause of the deep split of American elites and, albeit to a smaller degree, of American society. But he became a symbol of that split and in many respects a force that makes it grow deeper and wider. The acute internal political standoff has highlighted both the strengths and weaknesses of the American democracy and exposed some remarkable mechanisms of the deep state, which Trump is firmly opposed to, if his speeches and tweets are to be believed. One should not exaggerate the fact that as he challenged the traditional 
establishment, Trump relied on the ideas, principles and values that have unexpectedly brought him closer to his main counteragents on the international scene-Xi Jinping and-in particular-Vladimir Putin. It is important, though, that this standoff has resulted in the loss of the presumption of ideological and moral superiority of the American sociopolitical model over all others.

Moreover, if we go back to Thucydides' narration of a fateful internal conflict in ancient Greece, it is worth remembering that the Peloponnesian War was initiated by an oligarchy faced with the risk of decline against a rising democracy. In his "History..." Thucydides attached no great importance to the differences in the political systems of the two main antagonists of the Peloponnesian War, but many modern projections of the classical conflict between a declining and a rising powers to China-U.S. relations pay much attention to the dictatorship/democracy controversy. It turns out that at the beginning of the 21 st century a democracy that is keen to retain its global dominance is trying to prevent the rise of powers that it regards as oligarchies or dictatorships. Psychologically, modern America finds it extremely uncomfortable to be associated not with progressive Athens, but with conservative Sparta.

There is, however, a direct behavioral analogy between the United States and Athens in the period of the Peloponnesian War. It is Athens' powerful expansion in the entire Mediterranean region, abuse of the trade embargo (the so-called Megarian psephisma of 432 B.C.), the actual expropriation by Athens of the common treasury of the Delian League (454 B.C.), and levies from the allies (nearly a twofold increase in the mandatory tax-phoros-in 427 B.C. and subsequent measures towards maximum mobilization of resources during the war). At the same time Athens arrogantly neglected the discontent of those who counted on its patronage. In comparing Athens' policies in the days of Pericles and Cleon and U.S. policies under Trump, American analysts Henry Farrell and Abraham Newman made a rather pessimistic forecast. According to their expectations, a considerable share of U.S. economic and political influence depends on the degree of trust that foreign countries and companies have in the American-dominated 
world financial structure. But abuse of this influence in pursuit of one's own selfish aims eventually leads to its total collapse (Farrell and Newman, 2020).

What makes the current situation so special is that the United States under Trump, objectively being in the position of Sparta at the moment it was losing the advantages of its domination, demonstrates precisely the type of behavior that led the rising power-Athens-to a military and geopolitical catastrophe. In this context it would be appropriate to say that not only the United States and China, but the whole world community may fall into what can be described as a double Thucydides trap. The perception of the global order held together by American dominance is changing fundamentally. Donald Trump has made a major contribution to undermining the legitimacy of this order and emasculating it morally and ideologically.

Trump obtained-together with the mandate of the U.S. president-a complete set of global hegemony instruments. He preferred to use it for addressing the United States' internal problems, which, strictly speaking, matches his 2016 election pledges. As a result, the "benevolent hegemon" emerged as a great power determined to monetize all advantages of its domination. Trump is not only demonstrating his attitude to allies as vassals and his contempt of international institutions, but with remarkable consistency has been showing a profoundly skeptical attitude towards the principles and goals of the liberal world order.

Although it looks like the U.S. system of alliances has passed this stress test, the internal unity of the collective West has been undermined. The neologism 'Westlessness' used in the headline of the 2020 Munich Security Conference main report reflects the West's recognition of the fact that it has lost its unity as a "relatively cohesive geopolitical configuration." However, the authors of the report could hardly imagine how fast the trends they considered would develop within a matter of weeks after the publication.

As it has been already noted, China will fall into the Thucydides trap due to the awareness that the U.S. has made up its mind to firmly resist China's rise out of the fear or uncertainty about the future. The 
United States is achieving a tactical advantage because it is imposing a confrontation at a moment when China still finds itself not strong enough for open struggle. Amid growing confrontation with Washington, the Chinese leadership's room for maneuver is shrinking. At a time when society is increasingly angered over Western antiChinese rhetoric and Sinophobia, the established balance of opinion is changing. The hardline policy, as represented by the daily Huanqiu Shibao (Global Times), is getting much stronger.

Today there are enough reasons to say that future development of international relations will be characterized by bipolarity. But U.S.Chinese bipolarity can be called "new" not only because it has taken the place of the extinct U.S-Soviet bipolarity. Both similarities with SovietU.S. confrontation and fundamental differences from it stand out very clearly. First and foremost, the current bipolarity is not the result of the distribution of spheres of influence among the victors in war. It does not have the groundwork identical to the Yalta-Potsdam system. On the contrary, its emergence required a "moment of American unipolarity" and a prolonged period of symbiotic relations between the U.S. and Chinese economies in the context of globalization at the end of the 20th century and the early 21 st century. The creation of the "Chinese pole" can be compared to the emergence of Athena from Zeus' skull. Next, in contrast to the U.S.-Soviet rivalry, the current bipolarity is not very ideologized. It is the U.S. that is now trying to emphasize its ideological component, while China shuns any ideologization quite successfully. At the same time, just as it was the case during the Cold War, the new bipolarity will be the main structuring factor of international interaction. But alongside competition between the United States and China for global domination, the influence of other centers of power will continue and even grow stronger. To describe the transformation of the world order most accurately it would be appropriate to use the formula "bipolarity overburdened by multipolarity."

Russia's position in the context of the new American-Chinese bipolarity appears to be quite paradoxical. Although it has abandoned the status of America's number one opponent to find itself in the class of second-rate rivals, Russia still remains one foot inside the Thucydides 
trap. In the longer term, this regrouping inside the global strategic triangle may somewhat expand Moscow's freedom of maneuver, but for the time being all fundamental conditions and factors of RussianU.S. confrontation are still in place. Consequently, there remain the reasons for solidarity with Beijing within the framework of strategic partnership. Hasty attempts at rhetorical distancing from both poles will by no means improve relations with the United States but will certainly do nothing to benefit relations on the Chinese track.

It is critical for Russia not to lose strategic autonomy, while retaining all advantages of special relations with China. As new bipolarity gets stronger, it will be much harder to do than it is now. Special concerns stem not so much from a possible emergence of new international legal obligations, as from the impact of economic and technological factors.

Besides, there are two very important factors. One is the possibility of power transition which may create serious systemic risks. This factor largely encouraged the creation in early 2020 of a constitutional basis for delaying power transition by more than ten years. But this delay may aggravate many risks, particularly if Russia fails to use this period for upgrading the system of political and social governance. The other factor is Russia's lacking clarity regarding its goals in the post-Soviet space in the future, above all, the perspectives of its (co)existence with Belarus and Ukraine. Just as in 2014 any major shift on this track may considerably change Russia's position in the global strategic triangle. In a sense, it is one of the other traps that should be looked out for next to the Thucydides trap where the United States and China have found themselves today.

\section{References}

Allison, G., 2017. Destined for War: Can America and China Escape Thucydides's Trap? Boston, MA: Houghton Mifflin Harcourt.

Barr, W. P., 2020. Attorney General William P. Barr Delivers the Keynote Address at the Department of Justice's China Initiative Conference. The United States Department of Justice, 6 February [online]. Available at: <https://www.justice. 
gov/opa/speech/attorney-general-william-p-barr-delivers-keynote-addressdepartment-justices-china> [Accessed 29 April 2020].

Bremmer, I., 2019. The End of the American Order: Ian Bremmer's Speech at 2019 GZERO Summit. Eurasia Group, 18 November [online]. Available at: $<$ https://www.eurasiagroup.net/live-post/end-of-american-order-ian-bremmer2019-gzero-summit-speech> [Accessed 23 April 2020].

Brzezinski, Z., 2017. How to Address Strategic Insecurity in a Turbulent Age. Huffington Post, 3 January [Online]. Available at: <https://www.huffpost.com/ entry/us-china-russia-relations_b_586955dbe4b0de3a08f8e3e0?section=us_ world $>$ [Accessed 1 May 2020].

Burrows, M. and Manning R., 2015. Kissinger's Nightmare: How an Inverted US-China-Russia May Be Game-Changer. Valdai Papers, No.33, November [online]. Available at: <https://valdaiclub.com/files/11410/> [Accessed 1 May 2020].

Degterev, D.A. and Istomin, I.A., 2015. Systemnoye modelirovaniye v mezhdunarodnyh otnosheniyah [System Modelling of International Relations]. Mirovaya ekonomika i mezhdunarodnye otnoshenia, 7, pp. 17-30.

Dittmer, L., 1981. The Strategic Triangle: An Elementary Game-Theoretical Analysis. World Politics, 33(4), pp. 485-515.

Dobbins, J., Schatz, H. and Wyne, A., 2018. Russia Is a Rogue, Not a Peer; China Is a Peer, Not a Rogue. Different Challenges, Different Responses. Santa Monica, CA: RAND Corporation.

Farrell, H., and Newman, A., 2020. The Twilight of America's Financial Empire. Foreign Affairs, 24 January [online]. Available at: <https://www.foreignaffairs. com/articles/2020-01-24/twilight-americas-financial-empire> [Accessed 29 April 2020].

Ferguson, N. and Schularick, M., 2007. "Chimerica" and the Global Asset Market Boom. International Finance, 10 (3), pp. 215-239.

Ferguson, N. and $\mathrm{Xu}, \mathrm{X}$., 2018. Making Chimerica Great Again. International Finance, 21(3), pp. 239-252.

Goldstein, J. and Freeman, J., 1990. Three-Way Street: Strategic Reciprocity in World Politics. Chicago: University of Chicago Press.

Jervis, R., 1997. System Effects: Complexity in Political and Social Life. Princeton: Princeton University Press. 
Kashin, V., 2019. Tacit Alliance: Russia and China Take Military Partnership to New Level. Carnegie Moscow Center, 22 October [online]. Available at: <https:// carnegie.ru/commentary/80136> [Accessed 29 April 2020].

Kissinger, H., 1979. The White House Years. Boston, Mass.: Little, Brown and Company.

Mearsheimer, J. and Walt, S., 2016. Case for Offshore Balancing. The Superior US Grand Strategy. Foreign Affairs, 95 (4), pp. 70-83.

Munich Security Report, 2020. Westlessness. [online]. Available at: <https:// securityconference.org/assets/user_upload/MunichSecurityReport2020.pdf> [Accessed 29 April 2020].

National Security Strategy, 2010. National Security Strategy of the United States of America. The White House, May [online]. Available at: <https:// obamawhitehouse.archives.gov/sites/default/files/rss_viewer/national_security_ strategy.pdf $>$ [Accessed 27 April 2020].

National Security Strategy, 2017. National Security Strategy of the United States of America. The White House, December [online]. Available at: <https://www. whitehouse.gov/wp-content/uploads/2017/12/NSS-Final-12-18-2017-0905.pdf > [Accessed 27 April 2020].

Navarro, P. and Autry, G., 2011. Death by China. Confronting the Dragon - A Global Call to Action. Upper Saddle River, NY: Person Prentice Hall.

President Xi's Speech, 2015. President Xi's Speech on China-U.S Ties. China Daily, 24 September [online]. Available at: <https://www.chinadaily.com.cn/ world/2015xivisitus/2015-09/24/content_21964069.htm> [Accessed 20 April 2020].

Valdai, 2019. Valdai Discussion Club Session, 3 October [online]. Available at: $<$ http://en.kremlin.ru/events/president/news/61719/videos> [Accessed 21 April 2020]. 